\title{
Comparative Study of ACI and BIS Methods of Concrete Mix Design and Demonstration of Cracking Pattern of Concrete Specimens
}

\author{
Deepak Kumar ${ }^{1}$, Ankush Kumar ${ }^{2}$, Praveen Kumar ${ }^{3}$ Neeraj Bains ${ }^{4}$ \\ 1, 2, 4, B.Tech Civil Engineering Student, Jawaharlal Nehru Government Engineering College, Sundernagar, Mandi (H.P.) ${ }^{3}$ Pursuing M.Tech \\ in Transportation Engineering from Chandigarh University.
}

\begin{abstract}
This study aims at comparison of BIS (Bureau of Indian Standards) and ACI (American Concrete Institute) methods of concrete mix design. However both methods are built on basis of some basic principles and empirical relations but some minor differences exist between them. M25, M35 and M45 grades of ordinary strength, medium strength and higher strength were chosen. 27 cube specimens (15 cm sides) and 27 cylindrical specimens (15 cm diameter, $30 \mathrm{~cm}$ height) were prepared by BIS and ACI concrete mix design methods respectively. These specimens were tested after 7 days, 14 days and 28 day of curing. Material quantities required for manufacturing one cubic meter concrete by both methods were calculated numerically under codal provisions. Some differences were found in quantities calculated by both methods. Major differences were noticed in compressive strengths of specimens made by both methods. It was also noticed that cracked specimens of both methods show a great similarity in their cracking pattern.
\end{abstract}

Keywords: BIS, ACI, Mix Design, W/C Ratio

\section{Introduction}

Concrete usage is increasing with the advancement of Indian economy boosting the infrastructure. Strength of concrete is studied as major parameter and subject for consideration into application in various areas. In simplest form, concrete is a mixture of paste and aggregates. The paste, composed of Portland cement and water, coats the surface of the fine and coarse aggregates. Through a chemical reaction called hydration, the paste hardens and gains strength to form the rock-like mass known as concrete. Within this process lies the key to a remarkable characteristic of concrete: it is plastic and malleable when freshly mixed, strong and durable when hardened. The key to achieving a strong, durable concrete rests in the careful selection and proportioning of its constituent ingredients. The properties and proportion of these ingredients plays a vital role in deciding the physical and chemical properties. Design mix methods helps in deciding the proportions, thus helps in promoting the best method. USA and India have developed their own methods of concrete design which are based on basic principle and empirical relation developed after a number of experiments conducted. This study evaluates the similarities and differences found between ACI (American Concrete Institute) and BIS (Bureau of Indian Standards) mix design methods. It compares the material quantities required for manufacturing one meter cube of concrete using both methods. It also compares the characteristic compressive strength of cube and cylindrical specimens after 7, 14 and 28 days of curing. In India, IS 10262: 2009 is followed for the concrete mix design. In USA code ACI 211.1-91 is used for mix design.

\section{Literature Review}

Some research work has been done in this field that gives some basic idea about comparison of BIS and ACI method of concrete mix design.
Singh Amarjit and Gautam Kamal, (2005) carried out a study and find out very important results. They concluded that BIS method performs better in case of lower strength mixes than higher strength mixes. The fines content in ACI is higher, which makes for higher workability. Presumably, It also contributes to increased strength as the voids are filled,. In the case of ISI, fine aggregate content is reduced as the design strength requirement goes up. Therefore, voids are likely to be higher for higher strengths, thus leading to decreased strength in such cases

M.c Nataraja et.al. (2010) examined the procedure of calculating the material quantities of both methods and draw an idea that in case of ACI method, fine aggregate content is calculated after calculating the coarse aggregate content. He also found that as the strength requirement increases the sand requirement goes on decreasing.

G. Rishi et. al. (2003) carried out experiment using sand of fineness modulus 2.4 to 2.6 along with $10 \mathrm{~mm}$ and $20 \mathrm{~mm}$ coarse aggregates in two ratios 50:50 and 33:67. He concluded that the strength of concrete goes on decreasing with increase in $\mathrm{W} / \mathrm{C}$ ratio irrespective of change in cement aggregate and fineness of cement.

Singh Ravinder and Verma S. K. (2015) suggested that the highest amount of aggregates is used in BIS method and least is in ACI method. For M25 grade the BIS method shows a vast increment in the split tensile strength as compared to M20 and achieved highest strength among the rest of the methods Overall behavior of M20 in terms of mechanical properties of concrete was observed much better than that of the M25. Even the performance of concrete designed as per ACI method was admirable for this grade of concrete

Dr. S. A. Deepa et. al. (2014) carried out a comparative study and said that the fine aggregate content in ACI is more 


\section{International Journal of Science and Research (IJSR) \\ ISSN (Online): 2319-7064}

Index Copernicus Value (2016): 79.57 | Impact Factor (2015): 6.391

than the BIS method of concrete mix design. He also said that, in BIS method of concrete mix design the coarse aggregate content is more as that of ACI method. This may result in more workable ACI mix as compared to BIS mix.

\section{Materials Used}

- Ordinary Portland pozzolana cement 43 grade 8112:1989)

- Crushed stone coarse aggregates of $20 \mathrm{~mm}$ and $10 \mathrm{~mm}$ in ratio 40:60 ( specific gravity 2.54 and dry rodded density of $1463.82 \mathrm{~kg} / \mathrm{m}^{3}$ )

- Natural river Bed fine aggregates ( specific gravity 2.47 and fineness modulus 3)

- Sika Viscocrete 4005 NS High performance Super plasticizing admixture (confirming to IS 9103:1999, ASTM C494)

- Drinkable ordinary tap water without undesirable foreign impurities.

\section{Experimental Programme}

Various tests performed on above listed materials to calculate their property parameters, required for concrete mix design. Although the parameters used for BIS and ACI are somewhat different. For defining same property of an ingredient, the parameter used in one method may be different from the other.

Table 4.1: parameters required for mix design

\begin{tabular}{|c|c|c|}
\hline parameters & $\begin{array}{c}\text { BIS } \\
\text { Method }\end{array}$ & $\begin{array}{c}\text { ACI } \\
\text { method }\end{array}$ \\
\hline $\begin{array}{c}\text { 28 days characteristic strength and } \\
\text { standard deviation }\end{array}$ & Yes & Yes \\
\hline $\begin{array}{c}\text { Degree of workability } \\
\text { Type and maximum size of } \\
\text { aggregates }\end{array}$ & Slump test & Slump test \\
\hline $\begin{array}{c}\text { Dry rodded weight of coarse } \\
\text { aggregates }\end{array}$ & No & Yes \\
\hline $\begin{array}{c}\text { Grading of fine aggregates } \\
\text { Specific gravity of ingredients }\end{array}$ & Grading Zone & $\begin{array}{c}\text { Fineness } \\
\text { Modulus }\end{array}$ \\
\hline Water content adjustment & Yes & Yes \\
\hline Exposure condition & No & Yes \\
\hline Air/Non-air entrainment & No & Yes \\
\hline Shape of mold & Cube & Cylinder \\
\hline
\end{tabular}

Sieve analysis of fine aggregates and coarse aggregates is carried out. Fineness modulus of fine aggregates is calculated as per code and grading zone find out as per code IS-383 1970. By observing the results of sieve analysis of coarse aggregate the nominal size of coarse aggregates is also noticed. Specific gravity of fine aggregates calculated using pycnometer method under code IS: 2720- 1980 part 3. Specific gravity of coarse aggregates calculated using method under code IS: 2386-1970 part 3. Moisture content in aggregates is also calculated by drying the aggregates in oven for 24 hours at 110 degree Celsius. After obtaining all data, quantity of materials required for preparing one meter cube concrete is calculated as per codes. In India, IS 10262: 2009 is followed for the concrete mix design. In USA code ACI 211.1-91 is used for mix design. Dry materials are fed in to the mixer and mixed dry @ 33 to 35 rpm. Now water calculated as per mix design is added slowly. Admixture is added in between adding half the total quantity of water. Prepared concrete is poured in to molds and compacted properly on compaction tables. 27 cube specimens $(15 \mathrm{~cm}$ sides) and 27 cylindrical specimens $(15 \mathrm{~cm}$ diameter, $30 \mathrm{~cm}$ height) are prepared by BIS and ACI concrete mix design methods respectively. Out of these 27 BIS specimens, 9 specimens are of M25, other 9 are of M35 and remaining 9 are made up of M45. Same is the case with the 27 specimen prepared using ACI concrete mix design method. After preparing these specimens, they are cured in a tank of water. These specimens are tested after 7, 14 and 28 days in digital compression testing machine as per code IS: 516-1959. The results of compressive strength are noted.

\section{Results and Discussion}

\subsection{Quantities of material}

Concrete mix design is done for M25, M35 and M45 by both BIS and ACI methods and quantities required for making one meter cube of concrete are calculated and enlisted in tabular form.

Table 5.1: Materials required for making $1 \mathrm{~m}^{3}$ concrete

\begin{tabular}{|c|c|c|c|c|}
\hline Ingredients & Methodology & M25 & M35 & M45 \\
\hline \multirow{2}{*}{ Water content (Kg) } & BIS & 163 & 157 & 153 \\
\cline { 2 - 5 } & ACI & 168 & 162 & 158 \\
\hline \multirow{2}{*}{ Cement Content (Kg) } & BIS & 388 & 424 & 451 \\
\cline { 2 - 5 } & ACI & 366 & 387 & 428 \\
\hline $\begin{array}{c}\text { Fine Aggregates } \\
(\mathrm{Kg})\end{array}$ & BIS & 704 & 697 & 692 \\
\cline { 2 - 5 } & ACI & 861 & 857 & 832 \\
\hline $\begin{array}{c}\text { Coarse } \\
\text { Aggregates }(\mathrm{Kg})\end{array}$ & BIS & 1086 & 1075 & 1067 \\
\cline { 2 - 5 } & ACI & 878 & 878 & 878 \\
\hline \multirow{2}{*}{ W/C Ratio } & BIS & 0.42 & 0.37 & 0.34 \\
\cline { 2 - 5 } & ACI & 0.46 & 0.42 & 0.37 \\
\hline \multirow{2}{\text{Admixture}}{ content $(\mathrm{Kg})$} & BIS & 1.94 & 2.97 & 4.05 \\
\cline { 2 - 5 } & ACI & 1.83 & 2.70 & 3.55 \\
\hline
\end{tabular}

The calculations indicate that although the design strength (characteristic strength) is the same, the proportion of the ingredients for BIS and ACI mixes are different. Although, the water content results are quite close, the w/c ratios are different, and therefore, the cement content is different between the BIS and ACI results. The calculations show that BIS uses higher cement content than ACI, although both methods tend to increase the cement quantity as the desired strength increases. The high cement content of the BIS method may be owing to the relatively low quality of Indian cement in earlier decades when the codes were produced. Another reason for the high content may be the fineness of Indian cement, which is about $225 \mathrm{~m}^{2} / \mathrm{kg}$, compared to American cement, $300-500 \mathrm{~m}^{2} / \mathrm{kg}$. Both methods indicate that fine aggregate content tends to decrease as the desired strength increases. The coarse aggregate content does not seem to change in the case of the ACI method, whereas this tendency is not stable in the case of the BIS method. The w/c ratio is higher in the ACI mix than BIS.

\section{Volume 6 Issue 12, December 2017}




\section{International Journal of Science and Research (IJSR) \\ ISSN (Online): 2319-7064}

Index Copernicus Value (2016): 79.57 | Impact Factor (2015): 6.391

\subsection{Compression testing results}

All cube BIS specimens of side $15 \mathrm{~cm}$ and cylindrical ACI specimens of diameter $15 \mathrm{~cm}$ and height $30 \mathrm{~cm}$, tested after 7, 14 and 28 days of curing period. Average strength of specimen is calculated and tabulated below. The results are also shown in graphical representation also.

Table 5.2: Average compressive strength

\begin{tabular}{|c|c|c|c|c|c|c|}
\hline \multirow{2}{*}{$\begin{array}{c}\text { Target } \\
\text { strength } \\
\text { ( Mpa) }\end{array}$} & \multicolumn{2}{|c|}{$\begin{array}{c}\text { Achieved Strength in BIS } \\
\text { method (MPa) }\end{array}$} & \multicolumn{3}{c|}{$\begin{array}{c}\text { Achieved Strength in } \\
\text { ACI method (MPa) }\end{array}$} \\
\cline { 2 - 7 } & 7 days & 14 days & 28 days & 7 days & 14 days & 28 days \\
\hline 25 & 25.2 & 31.5 & 38.1 & 18.8 & 19.8 & 25.0 \\
\hline 35 & 28.0 & 33.2 & 39.5 & 27.6 & 34.6 & 42.2 \\
\hline 45 & 35.8 & 38.1 & 43.0 & 36.0 & 42.6 & 48.3 \\
\hline
\end{tabular}

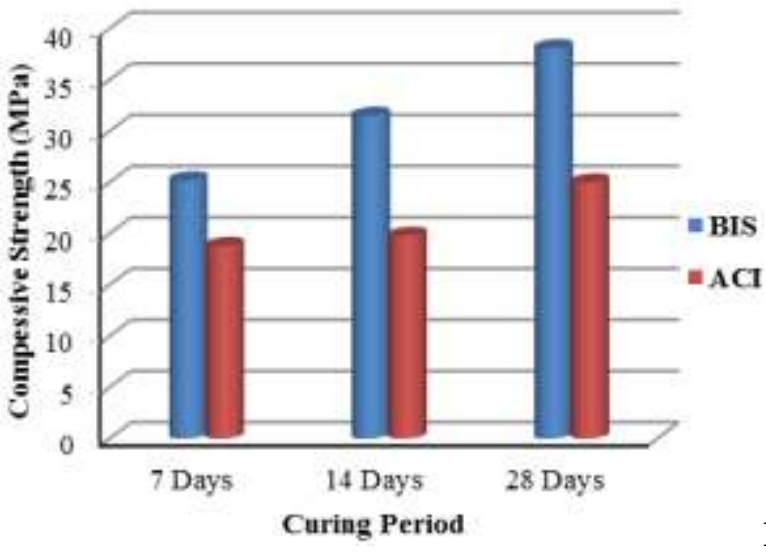

e 5.1: Compressive Strength of M25

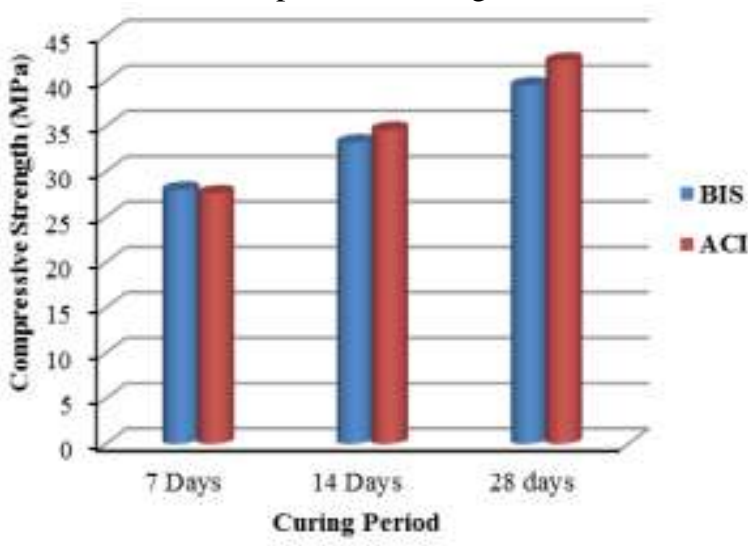

Figure 5.2: Compressive strength of M35

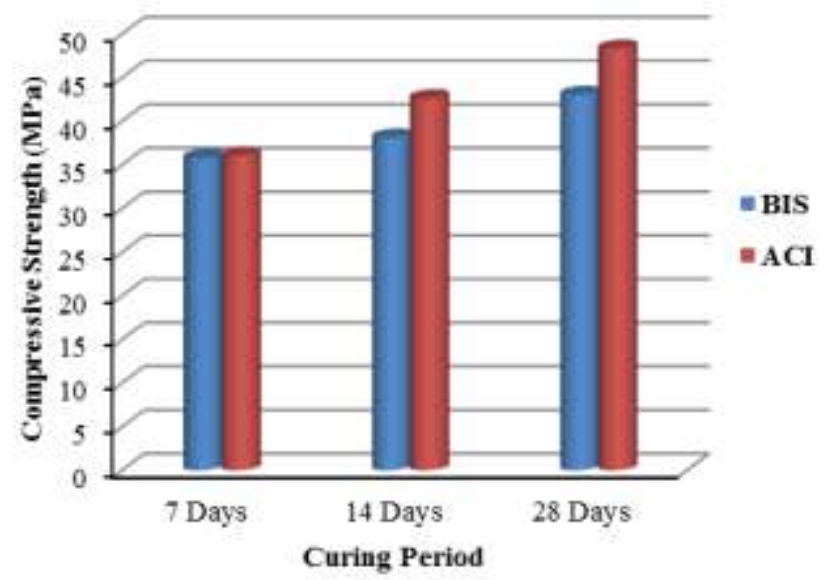

Figure 5.3: Compressive strength of M45
From graphical presentation it is clear that for low strength of M25 mixes BIS method gives better results as compared to ACI mixes. Although for high strength mixes ACI methods give better results as that of BIS. Figure 5.1 shows that strength gain in BIS method is very rapid as compared to ACI method for low strength mix of M25. Figure 5.2 and figure 5.3 shows that 7 days strength of M 35 and M45 mix is almost same. But after 14 days, strength gain in ACI mixes leads BIS mixes and finally they show better results.

\subsection{Demonstration of concrete specimen cracking pattern}

Crack behavior of specimen shows that cracking pattern followed by both BIS and ACI specimens is similar. Greater similarities were found between the shapes of broken specimens after 28 days compressive strength test. It was also observed that M25 samples collapse by gentle crushing. M35 samples and M45 samples get fractured by sudden brittle fracture. It was also observed that the shape of broken specimens changes with respect to increase in strength.

Figur
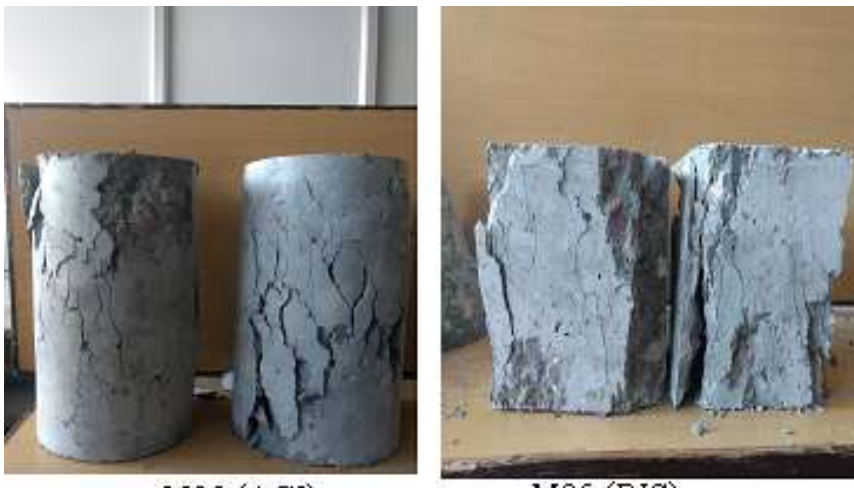

$\mathrm{M} 25(\mathrm{ACI})$

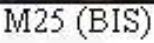

Figure 5.6: Cracking pattern of M25

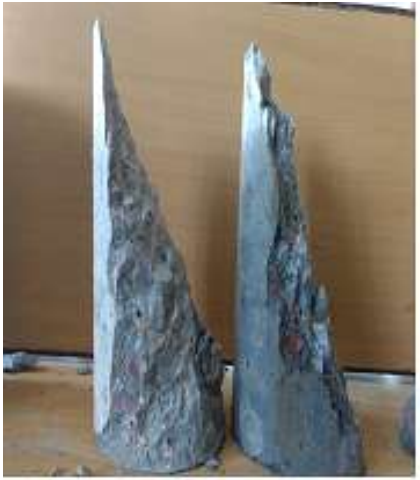

M35 (ACI)

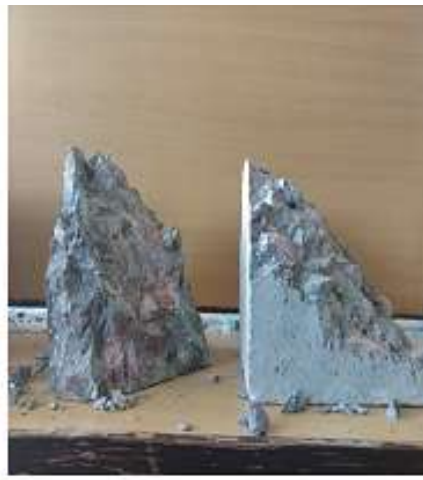

M35 (BIS)
Figure 5.7: Cracking pattern of M35

Volume 6 Issue 12, December 2017

www.ijsr.net 


\section{International Journal of Science and Research (IJSR) \\ ISSN (Online): 2319-7064}

Index Copernicus Value (2016): 79.57 | Impact Factor (2015): 6.391

M45 (ACI)

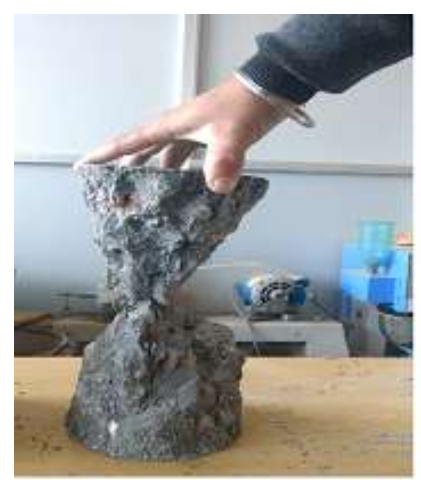

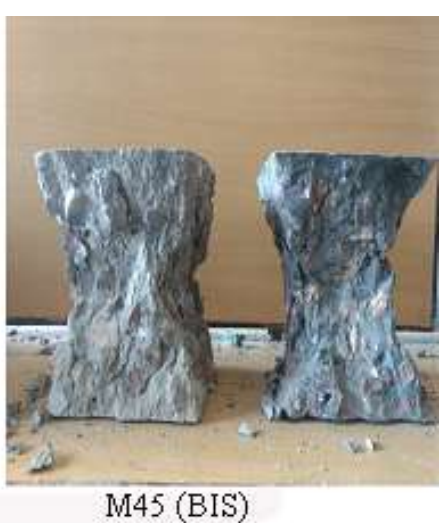

M45 (BIS)
Figure 5.8: Cracking pattern of M45

M25 specimens (fig. 5.6) break by gentle crushing with formation of numerous cracks in planes parallel to the application of load.M35 specimens (fig. 5.7) follow a single diagonal crack pattern, which start from top left of specimen and ends at the bottom right of it. In case of M45 (fig 5.8), specimens follow two inverted cone shape. As the figure depicts that ACI M45 specimens break in two fragments but in case of BIS M45 it does not happen.

\section{Conclusion}

\subsection{Similarities}

- Both methodologies are based on same empirical relationships obtained by the experimental result data.

- W/C ratio is the main fundamental criteria which is to be set to achieve the required target strength in both the methodologies

- In ACI and BIS the specimens of same strength follow same fracture pattern during failure.

\subsection{Differences}

- Compressive Strength: For lower strength i.e. M25 concrete BIS method provides much higher strength than that of ACI method. For higher grades of M35 and M45, ACI method mix gives higher strength than that of BIS method.

- W/C ratio: Codal provision of ACI mixes use higher W/C ratio than BIS.

- Water content: ACI method uses slightly higher water content as that of BIS method. This leads to more cohesive ACI mixes leading to better workability. In BIS mixes, water content is calculated on basis of nominal maximum size aggregates (NMSA) and required slump value. In ACI mixes water content calculated on basis of NMSA, air entrainment and slump range.

- Cement Content: BIS mixes consumes higher cement contents. This may be due to the reason that American cements are much finer as that of Indian cements. Use of higher cement contents make BIS method uneconomical

- Coarse Aggregates: In BIS method coarse aggregates content is selected on basis of NMSA and grading of fine aggregates. In ACI method coarse aggregates content selected on basis of fineness modulus and NMSA. It is to be noted that coarse aggregates content reduces with increase in strength for BIS method. Where in case of ACI method Coarse aggregates content remains constant with change in strength

- Fine Aggregates: Fine aggregates content goes on decreasing with increase in strength. But ACI method uses higher fine aggregates content than BIS. This provides denser concrete mix of ACI as that of BIS, leading to higher strength.

\section{References}

[1] Singh Amarjit and Gautam Kamal,(2005).“Comparison of BIS and ACI methods for Absolute Volume Concrete Mix Design." CI-PREMIER PTE LTD conference on "Our World in Concrete and structures."

[2] G. Rishi, "Concrete Mix Design Using Artificial Neural Network", 2003

[3] M.C. Nataraja and Lelin Das, "Concrete Mix Proportioning as per IS 10262:2009 - Comparison with IS 10262:1982 and ACI 211.1-91" The Indian Concrete Journal, September 2010.

[4] Deepa. A Sinha, "Compressive Strength of Concrete using Different Mix Design Methods", Volume: 4, Issue: 7, July 2014, ISSN - 2249-555.

[5] Ravinder Singh and S.K. Verma, "Comparative Study of M20 and M25 grades of Concrete by ACI, DOE and BIS Methods of Mix Design Using Crushed Aggregate" International Journal of Scientific Research and Management (IJSRM), 5,(7),6377-6383

[6] Bureau of India Standard, "Indian Standard Concrete Mix Proportioning- Guidelines”, (First Revision) IS10262:2009, New Delhi, India

[7] ACI Committee 211, 1991 (re-approved in 2002), "Standard practice for selecting proportions for normal, heavyweight and mass concrete. American Concrete Institute", USA

[8] Bureau of India Standard, "Code of practice for plain and reinforced concrete", fourth edition, IS-456; 2000, New Delhi.

\section{Author profile}

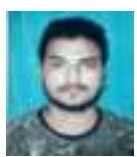

Deepak Kumar received his B.Tech. Degree in Civil Engineering from Jawaharlal Nehru Government Engineering College, Sundernagar, Mandi (H.P.), India in year 2017

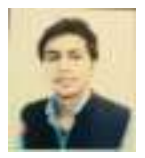

Ankush Kumar received his B.Tech. Degree in Civil Engineering from Jawaharlal Nehru Government Engineering College, Sundernagar, Mandi (H.P.), India in year 2017

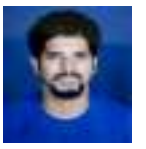

Praveen Kumar received his B.Tech. Degree in Civil Engineering from Jawaharlal Nehru Government Engineering College, Sundernagar, Mandi (H.P), India in year 2017,Pursuing Master Degree in Transportation Engineering from Chandigarh University

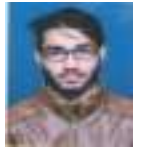

Neeraj Bains received his B.Tech. Degree in Civil Engineering from Jawaharlal Nehru Government Engineering College, Sundernagar, Mandi (H.P), India in year 2017 